\title{
The occurrence of herbicide-resistant Avena fatua (wild oats) populations to ACCase-inhibiting herbicides in Ireland
}

\author{
R. Byrne ${ }^{1,2}$, A.V. Vijaya Bhaskar ${ }^{1}$, J. Spink ${ }^{1}$, R. Freckleton ${ }^{2}$, P. Neve ${ }^{3}$ and S. Barth ${ }^{1 \dagger}$ \\ ${ }^{1}$ Teagasc, Crops Research Centre, Oak Park, Carlow R93 XE12, Ireland \\ ${ }^{2}$ Department of Animal and Plant Sciences, University of Sheffield, Sheffield S10 2TN, UK \\ ${ }^{3}$ Rothamsted Research, Harpenden, Hertfordshire AL5 2JQ, UK
}

Abstract

Following growers' reports of herbicide control problems, populations of 30 wild oats, Avena fatua, were collected from the south-east main arable counties of Ireland in 2016 and investigated for the occurrence and potential for herbicide resistance to acetyl-CoA carboxylase (ACCase) inhibitors pinoxaden, propaquizafop and cycloxydim, as well as acetolactate synthase (ALS) inhibitor mesosulfuron + iodosulfuron. Plant survival $\geq 20 \%$ was considered as the discriminating threshold between resistant and susceptible populations, when plants were treated with full recommended field rates of ACCase/ALS inhibitors. Glasshouse sensitivity screens revealed 2 out of 30 populations were cross-resistant to all three ACCase inhibitors. While three populations were cross-resistant to both pinoxaden and propaquizafop, and additionally, two populations were resistant to propaquizafop only. Different degree of resistance and cross-resistance between resistant populations suggest the involvement of either different point mutations or more than one resistance mechanism. Nevertheless, all populations including the seven ACCase-resistant populations were equally susceptible to ALS inhibitor. An integrated weed management (cultural/non-chemical control tactics and judicious use of herbicides) approach is strongly recommended to minimize the risk of herbicide resistance evolution.

Keywords

ACCase inhibitors $\bullet$ Avena fatua $\bullet$ cross-resistance $\bullet$ Herbicide resistance $\bullet$ Integrated weed management

\section{Introduction}

Wild oats, Avena fatua L., is a largely self-pollinated, predominantly spring-germinating and is a common annual grass weed widely spread in Ireland. It is a highly competitive weed and seed bank populations can build up rapidly if not controlled, causing important losses in crop yield (Owen \& Powles, 2009; Beckie et al., 2012). Across crop establishment systems, $A$. fatua infestations are influenced by cereal monoculture or tight crop rotation in combination with annual application of crop-selective post-emergent herbicides.

Acetyl-CoA carboxylase (ACCase) inhibitors are the most commonly used post-emergent herbicides for $A$. fatua control followed by acetolactate synthase (ALS) inhibitors. The phenylpyrazoline (DEN), aryloxyphenoxypropionates (FOP) and cyclohexanediones (DIM) chemical classes of ACCase inhibitors selectively inhibit homomeric plastidic ACCase found in most grass species (Incledon \& Hall, 1997). These herbicides halt ACCase enzyme activity by inhibiting fatty acid biosynthesis (Kaundun, 2014). While the ALS inhibitors inhibit the synthesis of three branched-chain amino acids: valine, leucine and isoleucine (Powles \& Yu, 2010). The ALS inhibitors involve five different chemical classes, sulfonlylureas (SU), imidazolinones, pyrimidinylthiobenzoates, sulfonylaminocarbonyltriazolinones and triazolopyrimidines. The repeated use of the same herbicide type is a key factor associated with the evolution of resistant weed populations. The main mechanism of resistance is either an altered ACCase or ALS gene (target site resistance, TSR) or enhanced herbicide metabolism (non-target site resistance, NTSR) by cytochrome P450 monooxygenases (CYP450) (Powles \& Yu, 2010). A number of ACCase/ALS-resistant $A$. fatua cases involving either the TSR or NTSR or sometimes both have been reported in several countries, including the United Kingdom (Moss et al., 2001), Canada (Beckie et al., 2012), Australia (Ahmad-Hamdani et al., 2013), the United States (Keith et al., 2015) and elsewhere (Heap, 2020). 
In this short research note, we report on the occurrence and potential for herbicide resistance in populations of $30 \mathrm{~A}$. fatua collected in 2016, where growers had reported weed control problems with ACCase-inhibiting herbicides pinoxaden, propaquizafop or cycloxydim at full recommended field rates. Understanding the occurrence and distribution of herbicideresistant weeds is critical to design resistance management strategies appropriate for our mild climate, yet the current understanding of herbicide resistance in $A$. fatua is limited.

\section{Materials and methods}

\section{Seed source}

Thirty $A$. fatua populations (population code: af1-af12 and af14-af31) from problem fields spread through Co. Donegal to Co. Tipperary (Figure 1) were collected in June 2016 for determining resistance to ACCase/ALS inhibitors. Seeds were collected from $A$. fatua plants that were found pre-harvest after herbicide programmes, and bulked. Additionally, one susceptible population af13 was collected in field margins from a Co. Kilkenny site, where they were unlikely to be subjected to as strong a selection pressure, to use as a susceptible control. The collected samples were left to after-ripen at room temperature for about $4 \mathrm{wk}$. Samples were stored in sealed envelopes and kept in a cold room at $4^{\circ} \mathrm{C}$ until used.

\section{Single-dose herbicide resistance bioassays}

In winter 2016, seeds were pricked and treated with $0.8 \%$ potassium nitrate $\left(\mathrm{KNO}_{3}\right)$ for $18-20 \mathrm{~h}$ and were sown in plastic trays containing a Kettering Loam and lime-free grit mix, with $1 \mathrm{~kg} / \mathrm{t}$ Osmocote Mini ${ }^{\mathrm{TM}}$. Trays were placed in an unheated glasshouse compartment reflecting natural outdoor conditions, at the Teagasc, Crops Research Centre, Oak Park, Carlow, Ireland. When seedlings had two leaves fully emerged, they were transplanted into $7 \times 7 \mathrm{~cm}^{2}$ pots containing the same soil mix. Herbicide treatments were applied to plants at the threeto four-leaf growth stage.

The response of all populations was assessed to three classes of ACCase inhibitors and an ALS-SU inhibitor at full recommended field rates, in total five herbicide treatments (Table 1). Treatment with pinoxaden was applied with $1 \% \mathrm{v} / \mathrm{v}$ aqueous adjuvant (Adigor ${ }^{\circledR} \mathrm{EC}, 47 \% \mathrm{w} / \mathrm{w}$ methylated rapeseed oil; Syngenta). Treatment with mesosulfuron + iodosulfuron was applied with $1 \% \mathrm{v} / \mathrm{v}$ aqueous adjuvant aqueous adjuvant (Biopower $^{\circledR}$ SC, 6.7\% w/w 3,6-dioxaeicosylsulphate sodium salt [EAC1] and 20.1\% w/w 3,6-dioxaoctadecylsulphate sodium salt [EAC2]; Bayer). Each treatment was applied to five replicated pots and three plants in the same pot. Herbicide treatments were applied using a DeVries track sprayer with a flat fan TeeJet nozzle, at a pressure of 2.5 bar and a water volume equivalent of $200 \mathrm{~L} / \mathrm{ha}$. After treatments, plants were left for $3 \mathrm{~h}$ before being moved back into the glasshouse compartment.

Visual assessment for survival was conducted $28 \mathrm{~d}$ after spraying and above ground plant material was harvested from each pot and fresh biomass was recorded. Plant survival was expressed as percentage of the number of treated plants. While fresh biomass from herbicide treatments was compared to the corresponding biomass of unsprayed plants from each population. Populations were considered resistant if $\geq 20 \%$ of the individuals survive the full recommended field rate of an herbicide (Owen \& Powles, 2009).

\section{Statistical analysis}

Data analyses were performed using $\mathrm{R}$, version 3.6.1. To determine the differences between $A$. fatua populations on survival or fresh biomass, a linear mixed-effects model was developed, with herbicide treatments and replicates as fixed effects and populations as random effects. This model was then compared with a generalised linear model, excluding populations. Model fit by Akaike's information criterion (AIC) suggested significantly $(P<0.01)$ better fit with the linear model having populations as random effects. Analysis of variance (ANOVA) revealed that the populations interacted significantly for both survival and fresh biomass when treated only with pinoxaden, propaquizafop and cycloxydim $(P<$ 0.001). A post hoc Bonferroni corrected Fisher's LSD test $(P<$ 0.05 ) was used to separate the treatment means.

\section{Results}

The susceptible population af13 was completely controlled by ACCase inhibitors pinoxaden, propaquizafop and cycloxydim at full recommended field rates (Figure 2). Out of the 30 populations screened, populations af6 and af28 were cross-resistant to all three ACCase inhibitors. In addition, populations af11, af27 and af2 2 were cross-resistant to both pinoxaden and propaquizafop, and populations af18 and af24 were resistant to propaquizafop only. While $100 \%$ of the tested $A$. fatua populations including those of the ACCaseresistant populations were equally susceptible ( $0 \%$ survival) to the ALS inhibitor mesosulfuron + iodosulfuron, and we did not find multiple resistance in $A$. fatua populations to both ACCase and ALS herbicide groups. The fresh biomass data largely followed the survival trends (data not shown).

\section{Discussion}

The main objective of this study was to identify whether there is an occurrence and potential for herbicide resistance in Irish populations of $A$. fatua to ACCase inhibitors pinoxaden, 


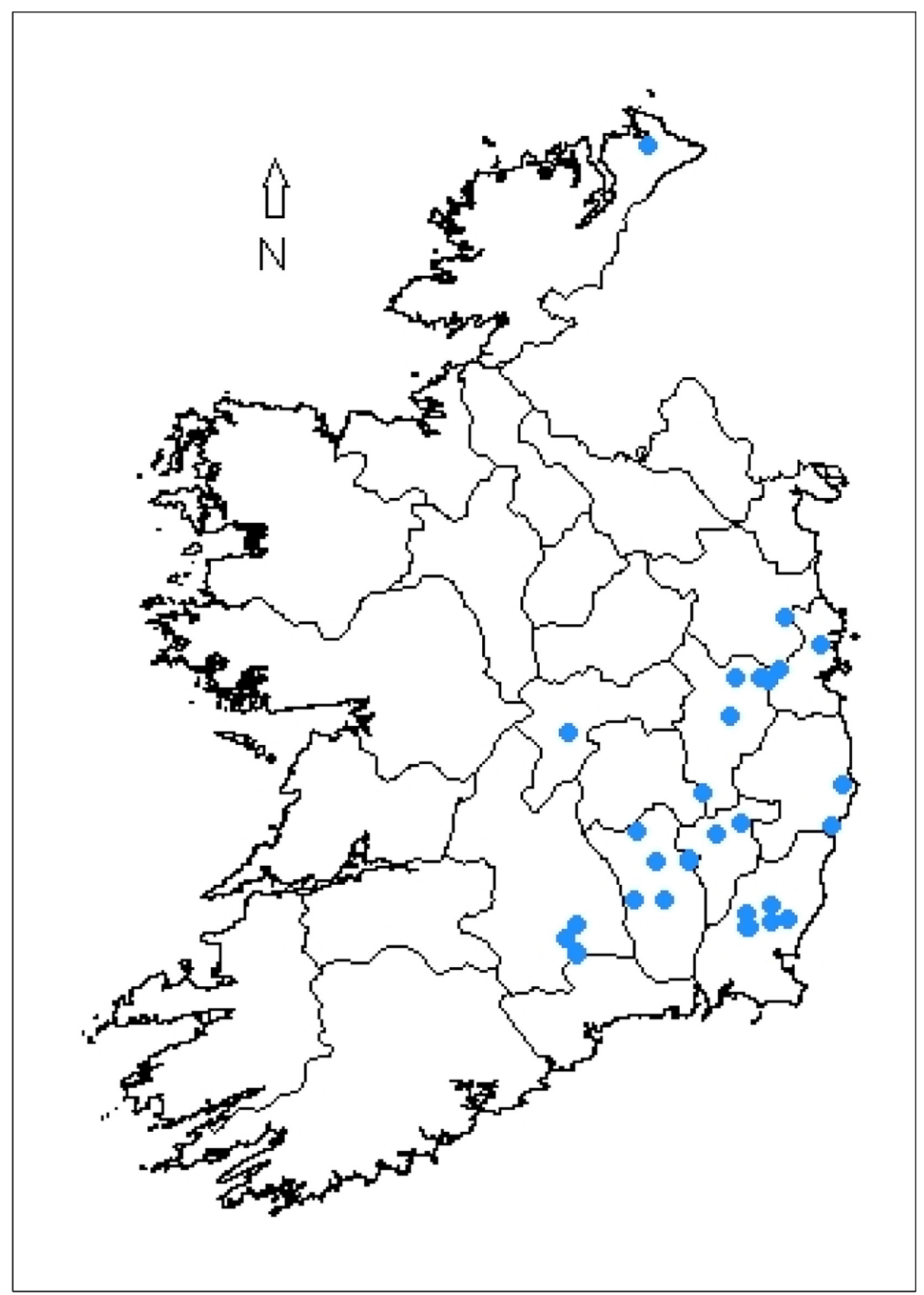

Figure 1. Geographical field position of Irish counties where A. fatua populations were collected for herbicide resistance testing.

propaquizafop and cycloxydim, as well as to the ALS inhibitor mesosulfuron + iodosulfuron at full recommended field rates. Glasshouse sensitivity studies suggested a degree of resistance in seven $A$. fatua populations to at least one ACCase actives, indicating that the full recommended field rates will no longer be effective on these populations. Owen \& Powles (2016) report that Australian growers often recognise resistance in the field when above $20 \%$ of a weed population survives herbicide application. However, plant survival $\geq 20 \%$ is an arbitrary figure and can depend on several factors including weed and/or crop density in the field. Most of the resistant populations in this study came from Co. Wexford, while counties Wicklow, Kilkenny and Meath recorded one case each. Consequently, resistance screening of 36 samples collected within Co. Wexford in 2017 revealed $>50 \% A$. fatua populations to have evolved resistance to at 
Table 1: ACCase/ALS inhibitor: single-dose herbicide treatments

\begin{tabular}{lccc}
\hline No. & Herbicide treatment & Active ingredients/products & Rate (g/ha) \\
\hline 1. & Untreated & & \\
2. & ACCase-DEN & Pinoxaden + cloquintocet (Axial ${ }^{\circledR}$; Syngenta) & 30 \\
3. & ACCase-FOP & Propaquizafop (Falcon ${ }^{\circledR}$ EC; Adama) & 100 \\
4. & ACCase-DIM & Cycloxydim (Stratos Ultra ${ }^{\circledR}$; BASF) & 150 \\
5. & ALS-SU & Mesosulfuron + iodosulfuron (Pacifica $^{\circledR}$ Plus; Bayer) & $15+5$ \\
\hline
\end{tabular}

$\mathrm{ACC}=$ acetyl-CoA carboxylase $; \mathrm{ALS}=$ acetolactate synthase.

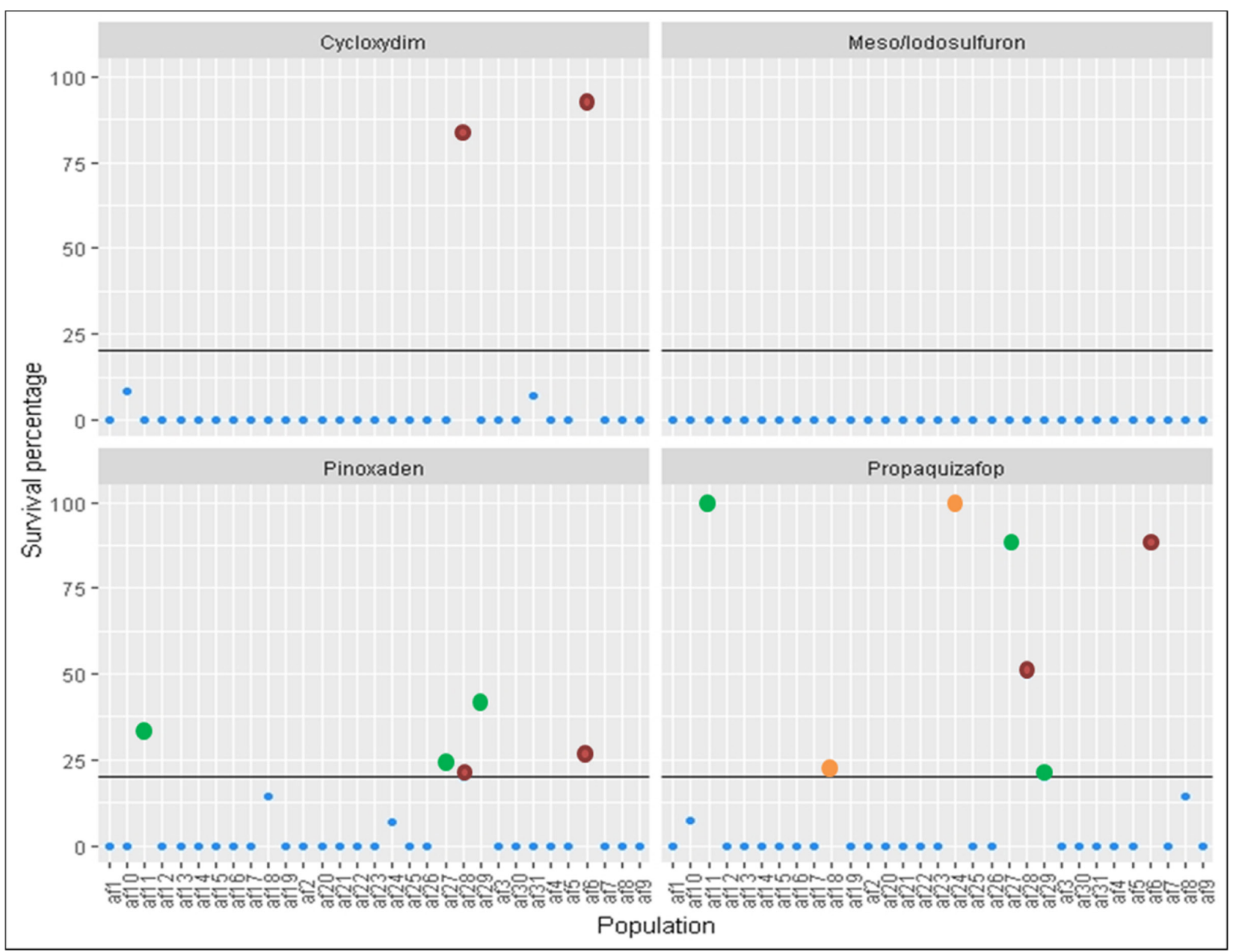

Figure 2. The average percentage survival of $A$. fatua populations to full recommended field rates of ACCase inhibitors pinoxaden, propaquizafop and cycloxydim, and ALS inhibitor mesosulfuron + iodosulfuron. Population af13 is an ACCase/ALS susceptible control. The horizontal line at $20 \%$ of plant survival represents the discriminating threshold between resistant and susceptible populations. Populations af6 and af28 (red circle) were cross-resistant to all three ACCase inhibitor; populations af11, af27 and af29 (green circle) were cross-resistant to pinoxaden and propaquizafop and populations af18 and af24 (orange circle) were resistant to propaquizafop only.

least one ACCase inhibitor at full recommended field rates (Byrne, 2019). More recently, we reported a detailed study on the cross-resistance of ACCase inhibitor-resistant $A$. fatua populations collected in 2019 from counties Kilkenny and Cork, in addition to Wexford (Vijaya Bhaskar et al., 2020). These results suggest that there is a high likelihood 
that resistant $A$. fatua may be widespread virtually to all of the south-east main arable counties.

The degree of resistance and cross-resistance patterns among the identified seven resistant populations were variable, suggesting the involvement of either different point mutations or more than one resistance mechanism. To understand the resistance mechanisms, TSR mutations and NTSR through enhanced metabolism by CYP450 inhibitors using pinoxaden dose-response with or without malathion (a known inhibitor of CYP450) was performed on two resistant populations af11 and af28. The result indicated that malathion + pinoxaden treatment either controlled or suppressed both populations, in conjunction a known TSR mutation was detected in both populations, I1781V and W2027C respectively. These results confirm TSR and/or NTSR mechanisms conferring ACCase resistance in Irish A. fatua populations (Byrne et al., unpublished results). Beckie et al. (2012) also found that NTSR was the key mechanism conferring ACCase/ALS resistance in Canadian populations of $A$. fatua. Additionally, several studies have reported the occurrence of both TSR and NTSR in single field populations of Avena spp. (e.g., Maneechote et al., 1997; Yu et al., 2013) and in cross-pollinated grass weed species (e.g. Neve \& Powles, 2005; Manalil et al., 2011).

The seven ACCase-resistant populations, however, recorded no resistance to ALS inhibitor mesosulfuron + iodosulfuron at full recommended field rates. Thus it is possible to manage these resistant populations by using alternative herbicide. But growers should note that the ALS-resistant $A$. fatua has been already documented in other countries. The majority of other screened populations that were susceptible but had herbicide control problems could be attributed to a number of factors. For example, seed dormancy and irregular germination of $A$. fatua substantially contribute to the persistence of unsprayed herbicide-susceptible individuals, despite herbicide interventions (Mansooji et al., 1992). Poor in-field $A$. fatua control could also be due to difficult spraying conditions or inaccurate spray timings, (Yu \& Powles, 2014).

Overall, our $A$. fatua herbicide studies suggest the need for growers and agronomists to use existing herbicides with caution by minimising selection pressure for resistance and ensuring the use of integrated weed management (IWM) approach. An IWM approach recommends the use of multiple cultural/non-chemical tactics as a first form of defence to reduce soil seed bank populations, and with use of herbicides for critical use only. This will ensure we retain effective control strategies in the future.

\section{References}

Ahmad-Hamdani, M.S., Yu, Q., Han, H., Cawthray, G.R., Wang, S.F. and Powles, S.B. 2013. Herbicide resistance endowed by enhanced rates of herbicide metabolism in wild oat (Avena spp.). Weed Science 61: 55-62.

Beckie, H.J., Warwick, S.I. and Sauder, C.A. 2012. Basis for herbicide resistance in Canadian populations of wild oat (Avena fatua). Weed Science 60: 10-18.

Byrne, R. Herbicide resistance in wild oats: what have we learned? Proceedings of the National Tillage Conference, Ireland, 30 January 2019, page 59. Available online: https://www.teagasc. ie/media/website/publications/2019/National-Tillage-ConferenceBooklet-2019.pdf [Accessed 09 April 2020].

Heap, I. 2020. The International Survey of Herbicide Resistant Weeds. Available online: www.weedscience.com [Accessed 28 March 2020].

Incledon, B.J. and Hall, J.C. 1997. Acetyl-coenzyme A carboxylase: quaternary structure and inhibition by graminicidal herbicides. Pesticide Biochemistry and Physiology 57: 255-271.

Kaundun, S.S. 2014. Resistance to acetyl-CoA carboxylase-inhibiting herbicides. Pest Management Science 70: 1405-1417.

Keith, B.K., Lehnhoff, E.A., Burns, E.E., Menalled, F.D. and Dyer, W.E. 2015. Characterisation of Avena fatua populations with resistance to multiple herbicides. Weed Research 55: 621-630.

Manalil, S., Busi, R., Renton, M. and Powles, S.B. 2011. Rapid evolution of herbicide resistance by low herbicide dosages. Weed Science 59: 210-217.

Maneechote, C., Preston, C. and Powles, S.B. 1997. A diclofopmethyl-resistant Avena sterilis biotype with a herbicide-resistant acetyl-coenzyme A carboxylase and enhanced metabolism of diclofop-methyl. Pesticide Science 49: 105-114.

Mansooji, A.M., Holtum, J.A., Boutsalis, P., Matthews, J.M. and Powles, S.B. 1992. Resistance to aryloxyphenoxypropionate herbicides in two wild oat species (Avena fatua and Avena sterilis ssp. Iudoviciana). Weed Science 40: 599-605.

Moss, S.R., Hughes, S.E., Blair, A.M. and Clarke, J.H. 2001. Developing strategies for reducing the risk from herbicide-resistant wild oats (Avena spp.) AHDB Project Report No. 266, UK.

Neve, P. and Powles, S. 2005. High survival frequencies at low herbicide use rates in populations of Lolium rigidum result in rapid evolution of herbicide resistance. Heredity 95: 485-492.

Owen, M.J. and Powles, S.B. 2009. Distribution and frequency of herbicide-resistant wild oat (Avena spp.) across the Western Australian grain belt. Crop and Pasture Science 60: 25-31.

Owen, M.J. and Powles, S.B. 2016. The frequency of herbicideresistant wild oat (Avena spp.) populations remains stable in Western Australian cropping fields. Crop and Pasture Science 67: $520-527$.

Powles, S.B. and Yu, Q. 2010. Evolution in action: plants resistant to herbicides. Annual Review of Plant Biology 61: 317-347.

Vijaya Bhaskar, A.V., Forristal, P.D., Cook, S.K., Staples, J., Schilder, D., Hennessy, M. and Barth, S. 2020. First report on assessing the severity of herbicide resistance to ACCase inhibitors pinoxaden, propaquizafop and cycloxydim in six Avena fatua populations in Ireland. Agronomy 10: 1362. 
Yu, Q. and Powles, S. 2014. Metabolism-based herbicide resistance and cross-resistance in crop weeds: a threat to herbicide sustainability and global crop production. Plant Physiology 166: 1106-1118.
Yu, Q., Ahmad-Hamdani, M.S., Han, H., Christoffers, M.J. and Powles, S.B. 2013. Herbicide resistance-endowing ACCase gene mutations in hexaploid wild oat (Avena fatua): insights into resistance evolution in a hexaploid species. Heredity 110: 220-231. 